Review

\title{
Steam Oxidation of Silicon Carbide at High Temperatures for the Application as Accident Tolerant Fuel Cladding, an Overview
}

\author{
Hai V. Pham ${ }^{1, *}$, Masaki Kurata ${ }^{1}$ and Martin Steinbrueck ${ }^{2}$ (D) \\ 1 Collaborative Laboratories for Advanced Decommissioning Science, Japan Atomic Energy Agency, \\ Fukushima 979-1151, Japan; kurata.masaki@jaea.go.jp \\ 2 Institute for Applied Materials-Applied Materials Physics (IAM-AWP), Karlsruhe Institute of Technology, \\ 76344 Eggenstein-Leopoldshafen, Germany; martin.steinbrueck@kit.edu \\ * Correspondence: pham.hai@jaea.go.jp
}

Citation: Pham, H.V.; Kurata, M.; Steinbrueck, M. Steam Oxidation of Silicon Carbide at High Temperatures for the Application as Accident Tolerant Fuel Cladding, an Overview. Thermo 2021, 1, 151-167. https:// doi.org/10.3390/thermo1020011

Academic Editor: Jean-Noël Jaubert

Received: 15 June 2021

Accepted: 21 July 2021

Published: 27 July 2021

Publisher's Note: MDPI stays neutral with regard to jurisdictional claims in published maps and institutional affiliations.

Copyright: (c) 2021 by the authors. Licensee MDPI, Basel, Switzerland. This article is an open access article distributed under the terms and conditions of the Creative Commons Attribution (CC BY) license (https:// creativecommons.org/licenses/by/ $4.0 /)$.

\begin{abstract}
Since the nuclear accident at Fukushima Daiichi Nuclear Power Station in 2011, a considerable number of studies have been conducted to develop accident tolerant fuel (ATF) claddings for safety enhancement of light water reactors. Among many potential ATF claddings, silicon carbide is one of the most promising candidates with many superior features suitable for nuclear applications. In spite of many potential benefits of $\mathrm{SiC}$ cladding, there are some concerns over the oxidation/corrosion resistance of the cladding, especially at extreme temperatures (up to $2000{ }^{\circ} \mathrm{C}$ ) in severe accidents. However, the study of $\mathrm{SiC}$ steam oxidation in conventional test facilities in water vapor atmospheres at temperatures above $1600^{\circ} \mathrm{C}$ is very challenging. In recent years, several efforts have been made to modify existing or to develop new advanced test facilities to perform material oxidation tests in steam environments typical of severe accident conditions. In this article, the authors outline the features of $\mathrm{SiC}$ oxidation/corrosion at high temperatures, as well as the developments of advanced test facilities in their laboratories, and, finally, give some of the current advances in understanding based on recent data obtained from those advanced test facilities.
\end{abstract}

Keywords: SiC; ATF; fuel cladding; steam oxidation

\section{Introduction}

The severe accident in 2011 at Fukushima Daiichi Nuclear Power Station (FDNPS) has stagnated the usage of nuclear energy but has also accelerated the research and development for safety enhancement of light water reactors (LWRs). Soon after the occurrence of the Great East Japan earthquake, emergency scram of the FDNPS operating reactors was activated automatically as were the emergency power supplies to ensure fuel cooling operations. However, approximately $50 \mathrm{~min}$ after the initial earthquake, a huge tsunami struck the station, flooding the emergency power supplies (particularly diesel generators), which led to a loss of the reactor core cooling, resulted in lowered coolant level in the Reactor Pressure Vessel (RPV), and a temperature increase of fuel cores. Initially, this loss of coolant accident (LOCA) resulted in decay heat temperature increases of approximately $0.5^{\circ} \mathrm{C} / \mathrm{s}$. When the fuel temperature attained around $1200-1400{ }^{\circ} \mathrm{C}$, then a steam oxidation of zirconium (major component of fuel claddings and channel box) with steam accelerated, generating a huge amount of hydrogen and significant chemical heat to drive temperatures higher. Furthermore, boron carbide $\left(\mathrm{B}_{4} \mathrm{C}\right.$, as a neutron absorber) contained in the control blade could react not only interact with the stainless steel (lowering its melting point) but also react with steam and further accelerate the hydrogen and heat generation, as seen in the following equations [1]:

$$
\mathrm{Zr}+2 \mathrm{H}_{2} \mathrm{O} \rightarrow \mathrm{ZrO}_{2}+2 \mathrm{H}_{2}(\Delta \mathrm{H}=-6.4 \mathrm{MJ} / \mathrm{kg}-\mathrm{Zr}),
$$




$$
\mathrm{B}_{4} \mathrm{C}+8 \mathrm{H}_{2} \mathrm{O} \rightarrow 2 \mathrm{~B}_{2} \mathrm{O}_{3}+\mathrm{CO}_{2}+8 \mathrm{H}_{2}\left(\Delta \mathrm{H}=-15 \mathrm{MJ} / \mathrm{kg}-\mathrm{B}_{4} \mathrm{C}\right) .
$$

Once the exothermic reactions of Zry and $\mathrm{B}_{4} \mathrm{C}$ in steam have started, they are hardly possible to mitigate or control. Besides the nuclear decay heat, these exothermic reactions became a significant heat source and result in local temperature escalations with prototypically $8{ }^{\circ} \mathrm{C} / \mathrm{s}$ to values where there is significant degradation (melting/slumping) of the fuel. Once fuel cores have lost their original geometry and loss of coolant channels, the retrieval of heat removal capability is very difficult, even when the cooling system has been revived due to the blockage of the coolant channel. The water/steam supply needs to be able to cool large melted fuel masses of low surface area/volume ratios.

The meltdown sequence starts from the failure of control blades, which is initiated by the eutectic reaction between $\mathrm{B}_{4} \mathrm{C}$ and $\mathrm{SS}$ at approximately $1250^{\circ} \mathrm{C}$ [2-7]. This temperature is far below the melting points of these components. The $\mathrm{B}_{4} \mathrm{C}$-SS melt then attacks the zircaloy (Zry) channel boxes and penetrating them to reach the fuel rods. The degradation of the irradiated fuel rods, consisting of $\mathrm{UO}_{2}$ fuel pellets in Zry cladding, starts with the liquefaction interaction between the partially oxidized inner $\operatorname{Zry}$ cladding $(\mathrm{Zr}(\mathrm{O}))$ and the $\mathrm{UO}_{2}$ pellet at around $1900{ }^{\circ} \mathrm{C}$ [8-10], far below the melting allows the release of gaseous and volatile fission products (FPs) collected in the clad free space to the external steam atmosphere.

Concepts of accident tolerant fuel (ATF) had been studied to mitigate or block these chemical interactions by introducing advanced fuel and cladding materials replacing either $\mathrm{UO}_{2}$ fuel and/or conventional Zry cladding [11]. Regarding the ATF-cladding, three major concepts have been proposed, such as silicon carbide [12,13], iron-based alloys [14-16], and coated zirconium-based claddings $[17,18]$. The motivation for transitioning away from the conventional Zry-cladding to the ATF-cladding alternatives is to delay or mitigate the chemical reactions and to reduce the amount of heat and hydrogen generation from the cladding steam oxidation of the. Each concept has a unique conceptual idea, based on the attributes of the base materials. For example, the concept of environmental barrier coatings of Zry is to delay or reduce the zirconium-steam interaction in the early stages. This concept is applicable to current nuclear safety technology and regulation as so-called "evolutionary" concept [11]. The idea of using iron-based alloys is to replace the major component of fuel cladding from zirconium to iron, which has "less heat generation capability", hence mitigating the catastrophic temperature increase and $\mathrm{H}_{2}$ generation in the early stage of accident. It also draws on the experience of rapid (fast neutron flux) reactors, where 316 stainless steels have been the standard cladding materials. Furthermore, $\mathrm{Al}$ and $\mathrm{Cr}$ as alloying elements should provide the capability to form protective oxide layers. The concept of replacing the major component of fuel cladding from zirconium to silicon carbide $(\mathrm{SiC})$ is to decrease the heat and hydrogen generation capabilities, and to maintain the fuel integrity even at high temperatures, which could maintain the ability to suppress the release of fission products. However, in order to use a ceramic material as a fuel cladding, a significant improvement of LWR-relevant conventional technologies is needed (hence, SiC-cladding is a so-called "revolutionary" concept).

Among the potential ATF cladding materials, $\mathrm{SiC}$ seems to stand out in terms of oxidation resistance $[19,20]$ and structural integrity at high temperatures $[21,22]$, high radiation damage tolerance [23,24], high thermal conductivity [25], and high neutron economy [26]. In spite of these potential benefits of SiC cladding, however, there are some key issues that need to be addressed for the LWRs application, such as hydrothermal corrosion and fission product retention capability $[23,27,28]$. The present review attempts to outline: (1) features of high temperature $\mathrm{SiC}$ corrosion by comparing relevant reactions in steam to those in air or oxygen atmospheres, (2) the further needs for improved test facilities for $\mathrm{SiC}$ steam corrosion tests, and (3) the current knowledge based on recent data obtained at Japan Atomic Energy Agency (JAEA) and Karlsruhe Institute of Technology (KIT). 


\section{Features of SiC Oxidation/Corrosion at High Temperatures in "Dry" and "Wet" Atmospheres and Remaining R\&D Issues for ATF-Cladding}

\subsection{Oxidation/Corrosion of SiC at High Temperatures in "Dry" Atmospheres}

As expected for high-temperature applications, such as components in gas turbine engines and LWRs, high-temperature oxidation of silicon carbide has been extensively studied in various environments and temperatures ranges. Oxidation of $\mathrm{SiC}$ at high temperatures in dry atmospheres, such as $\mathrm{O}_{2} / \mathrm{Ar}, \mathrm{CO}_{2} / \mathrm{CO}$ environments, and technical helium gas as used in high-temperature gas-cooled reactors [29-33], can be classified into three features as active oxidation, passive oxidation and bubble formation [34-37]. At high oxygen potentials, the oxidation of $\mathrm{SiC}$ results in formation of a protective $\mathrm{SiO}_{2}$ layer accompanying a mass gain, which is termed "passive oxidation" [34,38]:

$$
\mathrm{SiC}_{(\mathrm{s})}+3 / 2 \mathrm{O}_{2(\mathrm{~g})}=\mathrm{SiO}_{2(\mathrm{~s})}+\mathrm{CO}_{(\mathrm{g})} .
$$

At lower oxygen potential, the oxidation of $\mathrm{SiC}$ at high temperatures induced a mass loss due to the formation of gaseous $\mathrm{SiO}$, which is termed "active oxidation" [34,38]:

$$
\mathrm{SiC}_{(\mathrm{s})}+2 \mathrm{SiO}_{2(\mathrm{~s})}=3 \mathrm{SiO}_{(\mathrm{g})}+\mathrm{CO}_{(\mathrm{g})}
$$

Figure 1 illustrates the expected weight change during the active and the passive oxidations which have been reported for $\mathrm{Si}$ and $\mathrm{SiC}[29,39,40]$. In the passive regime, the chemical reaction, as shown in Equation (3), results in the formation of protective $\mathrm{SiO}_{2}$, thus inducing a mass gain, whereas, in the active regime, the chemical reaction as shown in Equation (4) occurs, which causes the volatilization of the surface $\mathrm{SiO}_{2}$ layer (formation of gaseous $\mathrm{SiO}$ ) and leads to a mass loss. Reaction 4 also indicates there is always a $\mathrm{SiO}_{2}$ surface layer to react with $\mathrm{SiC}$ substrate to form volatile $\mathrm{SiO}(\mathrm{g})$, and there is no $\mathrm{SiC}$ surface layer in contact with the atmosphere.

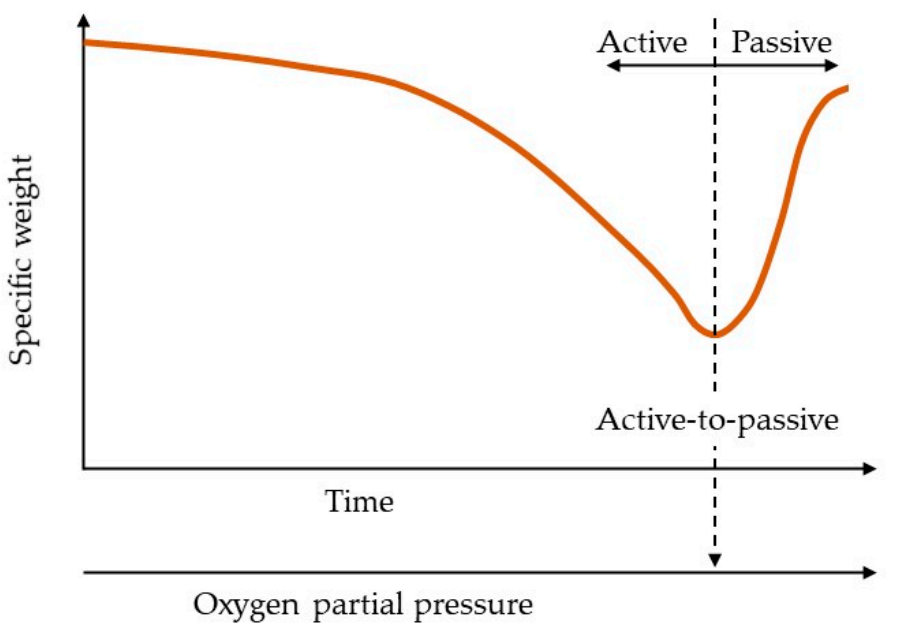

Figure 1. Schematic diagram on weight change during active and passive oxidations of $\mathrm{SiC}$ according to oxygen partial pressure (drawn by the authors referring to data reported by Jacobson [39]).

Oxidation mechanisms in active regime and the active-to-passive transitions can be classified into two types [40], as shown in Figure 2, according to the ambient environments. For example, Goto [38] observed a clear transition of active-to-passive of $\mathrm{SiC}$ in $\mathrm{O}_{2}-\mathrm{Ar}$ environment at $1600{ }^{\circ} \mathrm{C}$, in which the mass loss proceeds up to $\mathrm{P}_{\mathrm{O} 2}=146 \mathrm{~Pa}$ (volatilization of $\mathrm{SiO}$ ), and, at $\mathrm{P}_{\mathrm{O} 2}=160 \mathrm{~Pa}$, mass gain occurs (volatilization of $\mathrm{SiO}$ ceases and formation of $\mathrm{SiO}_{2}$ as a non-volatile and protective layer dominates). The oxidation behavior of $\mathrm{SiC}$ in $\mathrm{CO} / \mathrm{CO}_{2}$ environment is a contrast to that in $\mathrm{O}_{2}-\mathrm{Ar}$ atmosphere. In active oxidation regime of $\mathrm{SiC}$, the active oxidation rate shows a maximum value at a certain value of $\mathrm{P}_{\mathrm{CO} 2} / \mathrm{P}_{\mathrm{CO}}$ ratio. It is suggested that the vaporization of $\mathrm{SiO}$ and formation of $\mathrm{SiO}_{2}$ in 
$\mathrm{CO} / \mathrm{CO}_{2}$ environment might proceed simultaneously (neither of them becomes dominant) during the active oxidation regime as the following reactions [37,40]:

$$
\begin{gathered}
\mathrm{SiC}_{(\mathrm{s})}+3 \mathrm{CO}_{2(\mathrm{~g})}=\mathrm{SiO}_{2(\mathrm{~s})}+4 \mathrm{CO}_{(\mathrm{g})}, \\
\mathrm{SiO}_{2(\mathrm{~s})}+\mathrm{CO}_{(\mathrm{g})}=\mathrm{SiO}_{(\mathrm{g})}+\mathrm{CO}_{2(\mathrm{~g})} .
\end{gathered}
$$

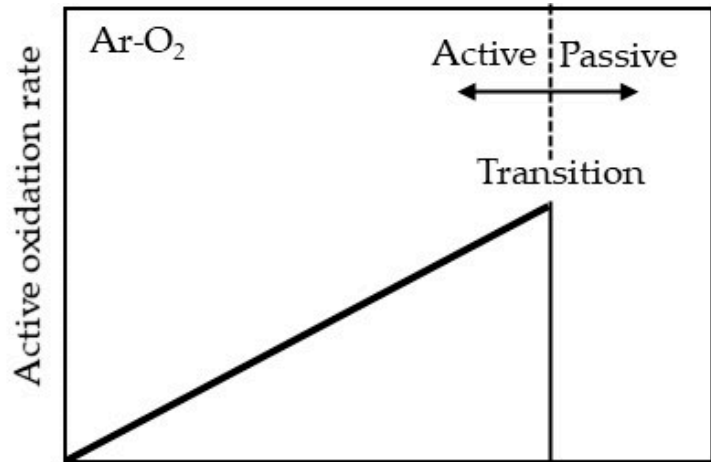

Oxygen Potential

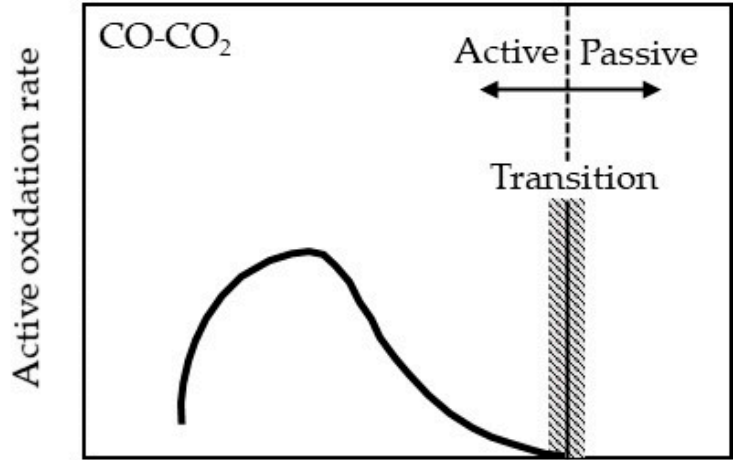

Oxygen Potential

Figure 2. Schematic diagram showing the differences of oxidation rate and active-to-passive transition of SiC oxidation in active regime in $\mathrm{Ar}-\mathrm{O}_{2}$ and $\mathrm{CO}-\mathrm{CO}_{2}$ atmospheres [40].

In other words, the high temperature oxidation behavior of SiC in dry air is fairly complicated and can vary according to the environment. Comprehensive reviews of $\mathrm{SiC}$ oxidation at high temperatures in various environments (dry and wet air) have been reported elsewhere $[39,40]$.

\subsection{Oxidation/Corrosion of SiC at High Temperatures in "Wet" Atmospheres}

The steam oxidation of $\mathrm{SiC}$ at high temperatures can be categorized into two different processes, known as $\mathrm{SiO}_{2}$ formation and its volatilization, as shown in Figure 3. At high temperatures, $\mathrm{SiC}$ reacts with water vapor to form $\mathrm{SiO}_{2}$ on the sample surface via the following reaction:

$$
\mathrm{SiC}_{(\mathrm{s})}+3 \mathrm{H}_{2} \mathrm{O}_{(\mathrm{g})}=\mathrm{SiO}_{2}+3 \mathrm{H}_{2(\mathrm{~g})}+\mathrm{CO}_{(\mathrm{g})} .
$$

The formation of $\mathrm{SiO}_{2}$ is the diffusion rate-controlled process, which depends on the diffusion of oxidizing species through the oxide layer, thus obeying parabolic laws. The kinetics due to the formation of the oxide layer is described by:

$$
\frac{d x_{1}}{d t}=\frac{k_{\mathrm{p}}}{2 x},
$$

where $x_{1}$ can be the mass gain or the thickness growth of the oxide scale. $k_{\mathrm{p}}$ is the parabolic rate constant and $t$ the time. The driving force of this process is the difference of steam partial pressure at the top surface and the interface of $\mathrm{SiO}_{2}-\mathrm{SiC}$. It means that the parabolic rate constant is proportional to the steam partial pressure on the top surface [41]:

$$
k_{\mathrm{p}} \propto P\left(\mathrm{H}_{2} \mathrm{O}\right)^{n},
$$

where $P\left(\mathrm{H}_{2} \mathrm{O}\right)$ is water vapor partial pressure, and $n$ the power law exponent. On the surface, the oxide scale reacts with water vapor at high temperatures and undergoes volatilization via, e.g., the following reaction:

$$
\mathrm{SiO}_{2(\mathrm{~s})}+2 \mathrm{H}_{2} \mathrm{O}_{(\mathrm{g})}=\mathrm{Si}(\mathrm{OH})_{4(\mathrm{~g})} .
$$


The volatilization of $\mathrm{SiO}_{2}$ depends on the chemical reaction on the surface, and transport of gaseous products away from the surface, thus obeying linear laws. The change due to the volatilization of $\mathrm{SiO}_{2}$ is described as:

$$
\frac{d x_{2}}{d t}=k_{1}
$$

where $x_{2}$ can be mass loss or thickness reduction of the $\mathrm{SiO}_{2}$ scale. $k_{1}$ is the linear rate constant and $t$ the time. According to Opila et al. [42], the linear constant $k_{1}$ is proportional to the velocity $(v)$ and total pressure $P_{\text {total }}$, as shown in the following equation:

$$
k_{1} \propto v^{1 / 2} \frac{P\left(\mathrm{H}_{2} \mathrm{O}\right)^{2}}{P_{\text {total }}^{1 / 2}} .
$$

As steam oxidation of $\mathrm{SiC}$ at high temperatures is a combination of the $\mathrm{SiO}_{2}$ formation and its volatilization, the mass/thickness evolution of the oxide scale follows the paralinear behavior [42,43] as shown in Equation (13).

$$
\frac{d x}{d t}=\frac{d x_{1}-d x_{2}}{d t}=\frac{k_{\mathrm{p}}}{2 x}-k_{1}
$$

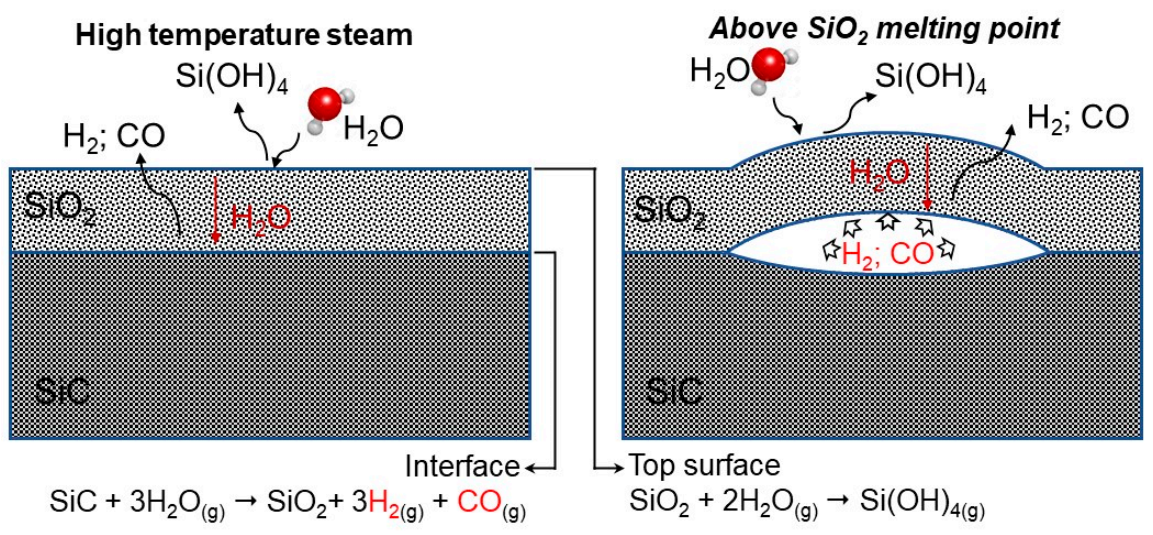

Figure 3. Illustration of $\mathrm{SiC}$ oxidation in steam at high temperatures.

The oxidation behavior of $\mathrm{SiC}$ in steam at high temperatures obeys paralinear kinetics, which can be different from the oxidation behavior of SiC in dry air, as shown in Figure 4. Oxidation mechanism of $\mathrm{SiC}$ in dry air can be either active or passive oxidation, depending on oxygen potential. In wet atmosphere, the formation of $\mathrm{SiO}_{2}$ at the $\mathrm{SiC}-\mathrm{SiO}_{2}$ interface and the volatilization of $\mathrm{SiO}_{2}$ on the top surface happens simultaneously, which results in paralinear kinetics. Therefore, the high temperature oxidation of $\mathrm{SiC}$ in steam environments should be discussed separately, especially for applications in LWRs.

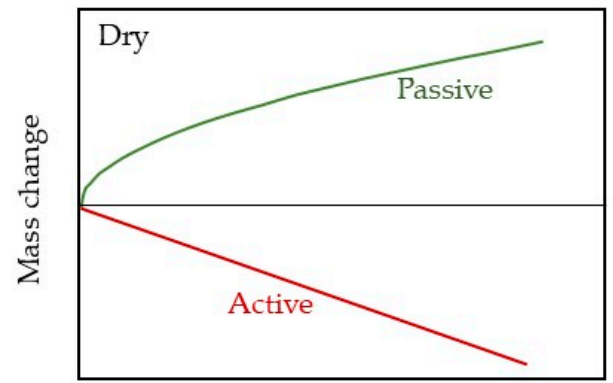

Time

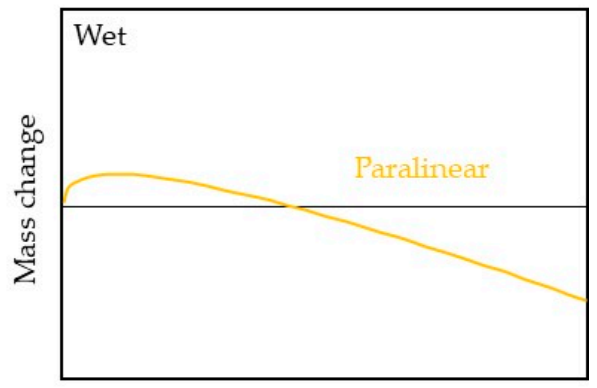

Time

Figure 4. Schematic image on oxidation kinetics of $\mathrm{SiC}$ at high temperatures in dry and wet atmospheres. 


\subsection{Oxidation Kinetics of SiC at High Temperatures and RED Issues for ATF-Cladding}

Oxidation behavior of $\mathrm{SiC}$ at high temperatures in wet air, such as $\mathrm{H}_{2} \mathrm{O} / \mathrm{Ar}$ [44-47] and $\mathrm{H}_{2} \mathrm{O} / \mathrm{O}_{2}[30,45,48]$, have been reported. One has to recognize an important difference in the steam oxidation of $\mathrm{SiC}$ in "wet" atmospheres, in which the formation of both a condensed $\mathrm{SiO}_{2}$ oxide and volatile phases, such as $\mathrm{Si}(\mathrm{OH})_{4}$, is induced at the same time. While the formation of $\mathrm{SiO}_{2}$ scale is a diffusion rate-controlled process, which obeys a parabolic law, the formation of volatile products depends on mass transport of the volatile products away from the surface, which yields linear kinetics $[49,50]$.

To obtain $k_{\mathrm{p}}$ and $k_{1}$ values based on Equation (13), one of the two terms $\left(k_{\mathrm{p}}, k_{1}\right)$ needs to be known. For example, Opila et al. [42] conducted a separate experiment to directly obtain the linear volatilization rate $\left(k_{1}\right)$ of $\mathrm{SiO}_{2}$ by exposing a fused quartz coupon to a $50 \% \mathrm{O}_{2} / 50 \% \mathrm{H}_{2} \mathrm{O}$ gas mixture using the thermogravimetric analysis (TGA) procedure. A similar solution has been proposed by Terrani et al. [13], in which electrically fused silica specimens were exposed in $100 \% \mathrm{H}_{2} \mathrm{O}$ using TGA and high temperature furnace (HTF) to obtain the volatilization rate $k_{1}$. The investigation conditions of the volatilization rate $\left(k_{1}\right)$ of $\mathrm{SiO}_{2}$ obtained by various authors are shown in Table 1. Experimental results of the investigations for linear volatilization rate of $\mathrm{SiO}_{2}$ reported by Opila [42] and Terrani [13] are summarized in Figure 5. After obtaining the volatilization rate $k_{1}$ of $\mathrm{SiO}_{2}$, the parabolic oxidation rate $k_{\mathrm{p}}$ can be determined by Equation (11) and the given experimental data (specifically, the mass change and investigation duration). Another method to obtain $k_{\mathrm{p}}$ and $k_{1}$ together is a curve fitting technique (nonlinear least-squares analysis) of experimental data. Observing the paralinear kinetics of $\mathrm{SiC}$, as well as the volatilization of fused silica, Opila concluded that the above techniques give similar results for the linear volatilization of $\mathrm{SiC}$ in water vapor [42].

Table 1. Investigation conditions of volatilization rate of $\mathrm{SiO}_{2}$ reported by various authors.

\begin{tabular}{cccccc}
\hline $\begin{array}{c}\text { Author } \\
\text { [Ref. No.] }\end{array}$ & Method & Specimen & Atmosphere & $\begin{array}{c}\text { Velocity, } \\
\mathbf{c m} / \mathbf{s}\end{array}$ & $\begin{array}{c}\text { Temperature } \\
\left({ }^{\circ} \mathbf{C}\right)\end{array}$ \\
\hline Opila [42] & TGA & $\mathrm{SiO}_{2}$ & $50 \% \mathrm{H}_{2} \mathrm{O} / \mathrm{O}_{2}$ & 4.4 & $1200-1400$ \\
\hline Opila [42] & TGA & Preoxidized $\mathrm{SiC}$ & $50 \% \mathrm{H}_{2} \mathrm{O} / \mathrm{O}_{2}$ & 4.4 & $1200-1400$ \\
\hline Terrani [13] & TGA & $\mathrm{SiO}_{2}$ & $100 \% \mathrm{H}_{2} \mathrm{O}$ & $1.3 \sim 1.6$ & $1200-1500$ \\
\hline Terrani [13] & HTF & $\mathrm{SiO}_{2}$ & $100 \% \mathrm{H}_{2} \mathrm{O}$ & $18 \sim 138$ & $1400-1600$ \\
\hline Pham [47] & LAHF & $\mathrm{SiC}$ & $97 \% \mathrm{H}_{2} \mathrm{O} / \mathrm{Ar}$ & 1200 & $1400-1800$ \\
\hline
\end{tabular}

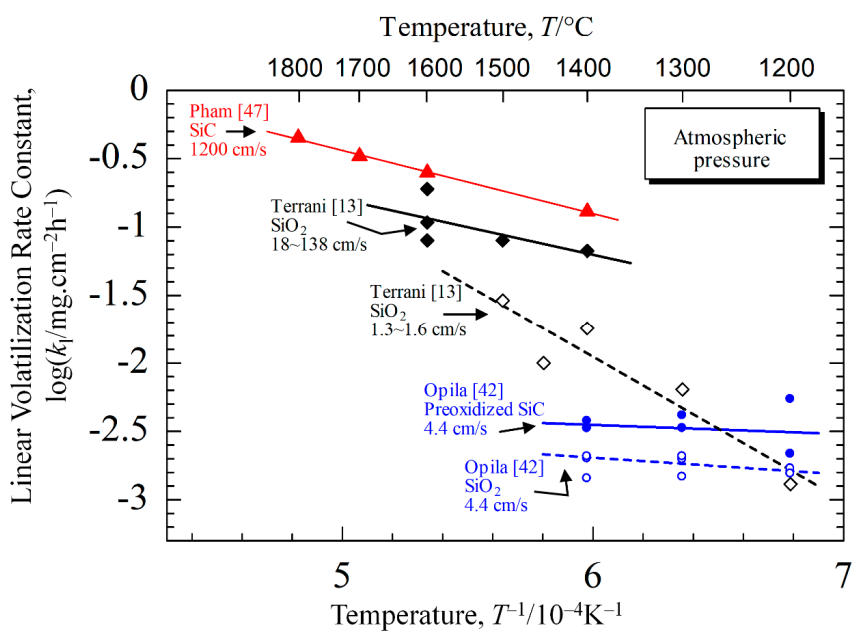

Figure 5. Summary of experimental results for linear volatilization rate of $\mathrm{SiO}_{2}$ reported by Opila [42], Terrani [13], and Pham [47]. 
As the parabolic oxidation rate constant $k_{\mathrm{p}}$ is proportional to the steam partial pressure, various authors have reported the oxidation kinetics of $\mathrm{SiC}$ in different environments. Table 2 briefly summarizes the investigation conditions of major studies for oxidation kinetics of CVD-SiC at high temperature in various steam partial pressures [13,42,45,47,48,51]. Representative results of these studies are presented in an Arrhenius-type diagram (Figure 6), which describes the relationship between logarithm of parabolic rate constant and reciprocal of temperature. The parabolic oxidation rate constant of $\mathrm{SiC}$ at a certain temperature, as shown in Figure 6, can vary, depending on many factors, such as the steam partial pressure and examination methods. The slopes (the activation energies) of the lines in Figure 6 give information about the diffusing species, which controls the process. In general, the activation energy for the permeation of a molecular species is less than that for the diffusion of a charged species, such as $\mathrm{OH}^{-}$and $\mathrm{O}^{2-}$. For example, Deal [52] concluded that the activation energies for the oxidation of silicon in dry oxygen and water vapor by permeation mechanism to be 119 and $68 \mathrm{~kJ} / \mathrm{mol}$, respectively. Narushima [48] reported that the activation energy for $\mathrm{SiC}$ oxidation in $10 \mathrm{vol} \% \mathrm{H}_{2} \mathrm{O} / \mathrm{O}_{2}$ was $397 \mathrm{~kJ} / \mathrm{mol}$ and stated that $\mathrm{O}^{2-}$ was the diffusing species. In another study, Doremus [53] discussed that the diffusion of charged oxygen species is expected to have an activation energy magnitude similar to the bond energies of Si-O and Si-OH bonds (approximately $377 \mathrm{~kJ} / \mathrm{mol}$ ). More details of discussion on the activation energy for oxidation of $\mathrm{SiC}$ at high temperatures can be found elsewhere [45].

Table 2. Investigation conditions of major studies for oxidation kinetics of $\mathrm{SiC}$ in steam.

\begin{tabular}{ccccc}
\hline $\begin{array}{c}\text { Author } \\
\text { [Ref. No.] }\end{array}$ & Method & Specimen & Atmosphere & $\begin{array}{c}\text { Temperature } \\
\left({ }^{\circ} \mathbf{C}\right)\end{array}$ \\
\hline Narushima [48] & TGA & CVD-SiC & $10 \% \mathrm{H}_{2} \mathrm{O} / \mathrm{O}_{2}$ & $1550-1650$ \\
\hline Opila [51] & TGA & CVD-SiC & $10 \% \mathrm{H}_{2} \mathrm{O} / \mathrm{O}_{2}$ & $1200-1400$ \\
\hline Opila [45] & HTF & CVD-SiC & $10 \% \mathrm{H}_{2} \mathrm{O} / \mathrm{O}_{2}$ & $1100-1400$ \\
\hline Opila [45] & HTF & CVD-SiC & $25 \% \mathrm{H}_{2} \mathrm{O} / \mathrm{O}_{2}$ & $1100-1400$ \\
\hline Opila [45] & HTF & CVD-SiC & $50 \% \mathrm{H}_{2} \mathrm{O}^{-\mathrm{O}_{2}}$ & $1100-1400$ \\
\hline Opila [42] & TGA & CVD-SiC & $50 \% \mathrm{H}_{2} \mathrm{O} / \mathrm{O}_{2}$ & $1200-1400$ \\
\hline Opila [45] & HTF & CVD-SiC & $70 \% \mathrm{H}_{2} \mathrm{O} / \mathrm{O}_{2}$ & $1100-1400$ \\
\hline Opila [45] & HTF & CVD-SiC & $90 \% \mathrm{H}_{2} \mathrm{O} / \mathrm{O}_{2}$ & $1100-1400$ \\
\hline Terrani [13] & TGA & CVD-SiC & $100 \% \mathrm{H}_{2} \mathrm{O}$ & $1200-1500$ \\
\hline Terrani [13] & HTF & CVD-SiC & $100 \% \mathrm{H}_{2} \mathrm{O}$ & $1400-1600$ \\
\hline Pham [47] & LAHF & Monolithic SiC & $97 \% \mathrm{H}_{2} \mathrm{O} / \mathrm{Ar}$ & $1400-1800$ \\
\hline
\end{tabular}

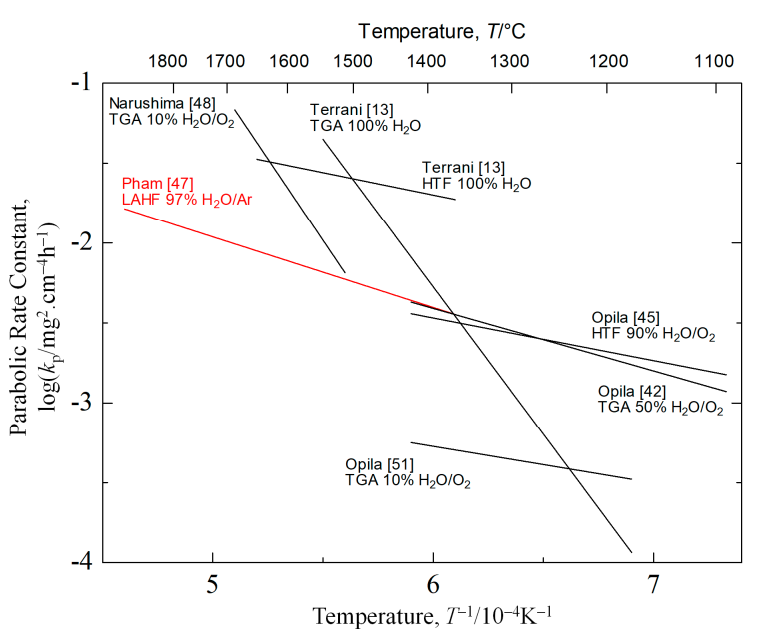

Figure 6. Major reports on the parabolic oxidation rate, $k_{\mathrm{p}}$, of $\mathrm{SiC}$ in steam at high temperatures. 
To investigate the influence of steam partial pressure on the parabolic oxidation rate of $\mathrm{SiC}$ (as seen in Equation (9)), Opila conducted oxidation tests of CVD-SiC at temperatures of $1100-1400{ }^{\circ} \mathrm{C}$ in $\mathrm{H}_{2} \mathrm{O} / \mathrm{O}_{2}$ gas mixtures with compositions of $10-90$ vol\% water vapor at a total pressure of 1 bar [45]. The results of the investigation are presented in Figure 7, where the parabolic oxidation rate constant increased with the increase of steam partial pressure. A range of possible activation energies of $28-156 \mathrm{~kJ} / \mathrm{mol}$ has been reported, which indicated that the molecular permeation mechanism is more dominant than a diffusion mechanism that involves a charged species.

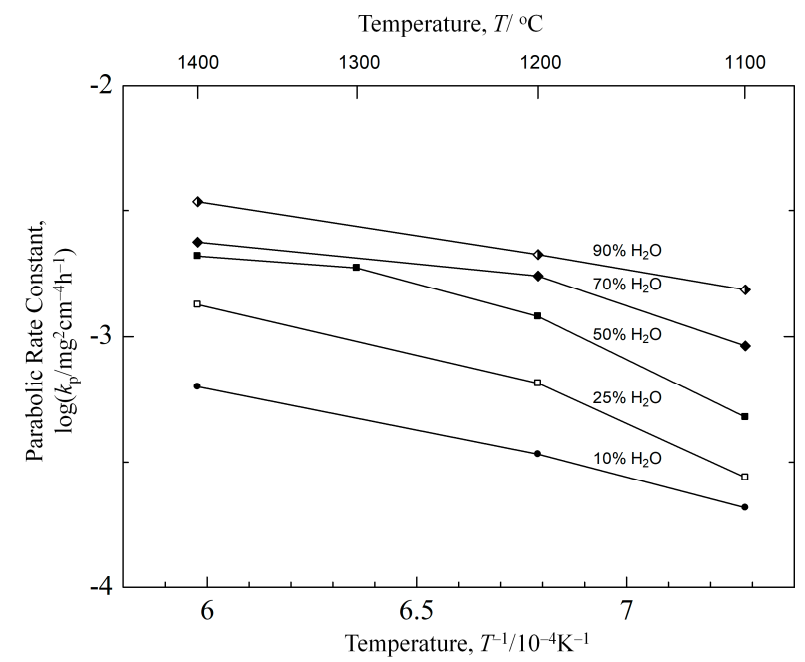

Figure 7. Influence of steam partial pressure on parabolic oxidation rate constant reported by Opila [45].

Impurities from environment can also affect the oxidation of $\mathrm{SiC}$ in steam at high temperatures. Opila [51] investigated the oxidation kinetics of CVD-SiC at $1200-1400{ }^{\circ} \mathrm{C}$ in $10 \mathrm{vol} \% \mathrm{H}_{2} \mathrm{O} / \mathrm{O}_{2}$ mixture using TGA with either pure $\mathrm{Al}_{2} \mathrm{O}_{3}$ or fused quartz reaction tubes. Results of the investigation (Figure 8 ) indicated that the parabolic oxidation rate of $\mathrm{SiC}$ samples tested in $\mathrm{Al}_{2} \mathrm{O}_{3}$ reaction tube was about one order of magnitude higher than that of $\mathrm{SiC}$ samples tested in quartz tube. It was found that the steam oxidation of $\mathrm{SiC}$ in $\mathrm{Al}_{2} \mathrm{O}_{3}$ reaction tube led to sodium and aluminum contamination of the oxide scale. The sodium and aluminum might be transported from the $\mathrm{Al}_{2} \mathrm{O}_{3}$ reaction tube to the $\mathrm{SiC}$ sample surface in the gas phase to form less protective oxide scales.

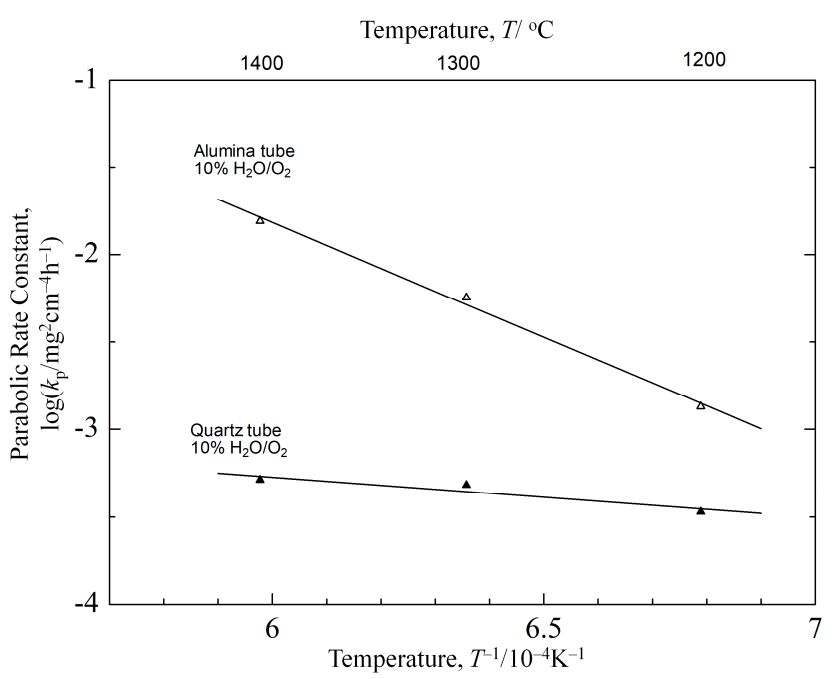

Figure 8. Effects of sodium and aluminum from the reaction tube (alumina tube) on parabolic oxidation rate of $\mathrm{SiC}$ in steam reported by Opila [51]. 
Due to the characteristics of the applications of $\mathrm{SiC}$, most of the oxidation studies of $\mathrm{SiC}$ focused at temperatures ranging from 1000 to $1600^{\circ} \mathrm{C}$. Although the normal cladding temperature of cladding is approximately $300{ }^{\circ} \mathrm{C}, \mathrm{SiC}$ ATF claddings may suffer temperatures over $2000{ }^{\circ} \mathrm{C}$ in the event of severe accidents [54]. It is necessary to verify the performance of $\mathrm{SiC}$ cladding, as well as other potential candidates for ATF claddings under severe accident conditions, above at least $1600^{\circ} \mathrm{C}$ in steam. However, the oxidation kinetics of $\mathrm{SiC}$ is still insufficient studied due to the lack of test facilities capable of operating in steam at temperatures above $1600^{\circ} \mathrm{C}$.

\section{Advanced Test Facilities for ATF-Claddings}

Steam oxidation tests at temperatures above $1600^{\circ} \mathrm{C}$ are very challenging as major refractory lining materials, such as alumina and even zirconia, in conventional test facilities are at their limits. In recent years, several efforts have been made to modify existing or to develop new test facilities $[46,47]$ to study $\mathrm{SiC}$ under extreme conditions. To perform the oxidation tests at temperatures higher than $1600{ }^{\circ} \mathrm{C}$, the QUENCH-SR facility with utilization of induction heating was developed at Karlsruhe Institute of Technology [55]. First oxidation and quench tests of $\mathrm{SiC}$ at temperatures up to $2000{ }^{\circ} \mathrm{C}$ in steam atmosphere were reported by Avincola et al. [46]. Under the same motivation, JAEA has also developed a new test facility (Laser Heating Facility: LAHF) with utilization of laser heating for oxidation tests at extreme temperatures [47]. In this section, we introduce these two facilities.

\subsection{Laser Heating Facility (LAHF)}

A schematic diagram of the laser heating facility is shown in Figure 9. This apparatus was designed for heat-treatment tests of small samples (less than $20 \mathrm{~mm}$ in diameter) in controlled environments (including vacuum) at temperatures beyond $1600{ }^{\circ} \mathrm{C}$. The main unit includes a laser head, vacuum pump, gas line heaters, flow rate controllers, and airtight test vessel which is equipped with two radiation pyrometers, a W-Re 5-26 thermocouple, and a video camera. Sample holders are made of zirconia. The laser light transmission, pyrometer temperature measurement, and in situ observation were made via five quartz windows (synthetic silica) located in the vessel wall. To avoid water vapor condensation, the test vessel, including gas pipes and quartz windows, are heated up to $200{ }^{\circ} \mathrm{C}$ using resistance heating. The flow rates can be controlled in the range of $0.1-3.0 \mathrm{~g} / \mathrm{min}$ (water vapor), $0.1-5.0 \mathrm{~L} / \mathrm{min}(=0.18-8.9 \mathrm{~g} / \mathrm{min})(\mathrm{Ar})$, and $0.06-3.14 \mathrm{~g} / \mathrm{min}$ (hydrogen), respectively. The $2500 \mathrm{~W}$ laser module allows the sample to be heated at the rate of $1000{ }^{\circ} \mathrm{C} / \mathrm{s}$. Parameters, such as laser beam power, sample temperatures, and gas flow rates, are monitored in a control system and recorded by a datalogger. After passing through a steam trap, outlet gases, such as hydrogen and carbon monoxide, are sampled and analyzed using a gas chromatograph.

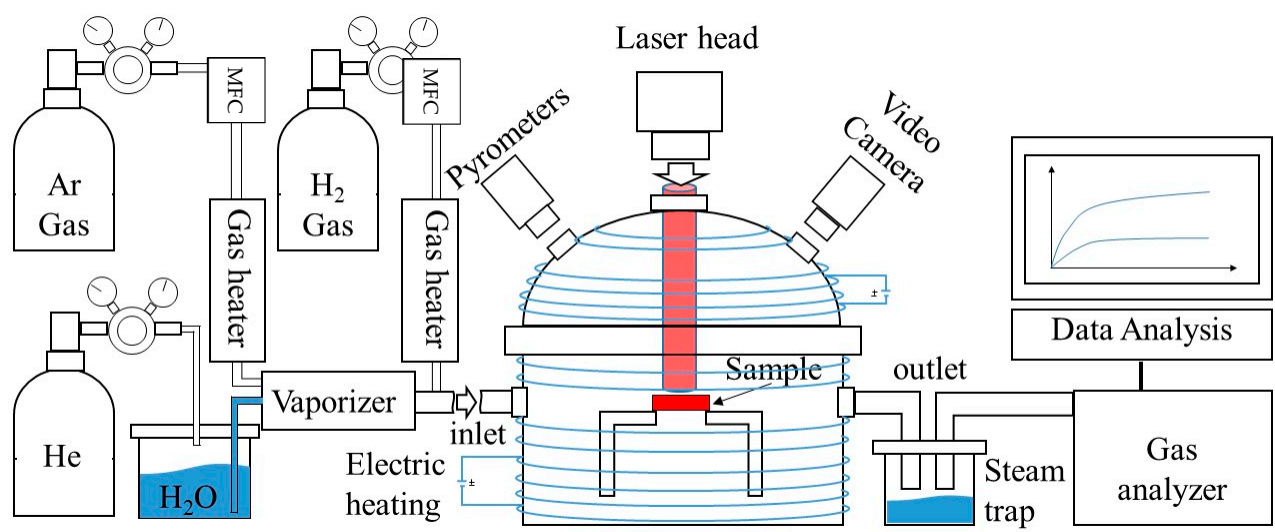

Figure 9. Schematic of the laser heating facility (LAHF) [47]. 
Figure 10 shows experimental data of a preliminary investigation for steam oxidation of CVD-SiC/SiC composites under 1 bar pressure, in a stream of $50 \% \mathrm{H}_{2} \mathrm{O} / \mathrm{Ar}$ gas mixture, and at temperatures up to $2200{ }^{\circ} \mathrm{C}$ with $0.1{ }^{\circ} \mathrm{C} / \mathrm{s}$ heating rate. In the temperature range of 200 to $1650{ }^{\circ} \mathrm{C}$, the LAHF was automatically controlled by feedback of the pyrometer detecting sample temperature at the periphery. Above $1650^{\circ} \mathrm{C}$, the LAHF was manually controlled because the feedbacks from pyrometers are no longer reliable (pyrometer measurement is affected by the change of sample surface and the formation of gaseous products during the test). Using the laser current output and the immediately preceding temperature trends (before the interference mentioned above), the surface temperature of the sample at the center is estimated. An example is shown in Figure 10a-d. Hydrogen production during the test can be divided into 3 stages (below $1800{ }^{\circ} \mathrm{C}, 1800-2000{ }^{\circ} \mathrm{C}$, and above $2000^{\circ} \mathrm{C}$ ). Below $1800^{\circ} \mathrm{C}$ (points a and b): before the appearance of bubbles, the amount of $\mathrm{H}_{2}$ produced during the test was less than $10 \mathrm{~L} / \mathrm{h} / \mathrm{m}^{2} \mathrm{SiC}$, indicating the excellent oxidation resistance in steam. In the temperature range of $1800-2000{ }^{\circ} \mathrm{C}$ (point c), the formation of bubbles on sample surface led to the degradation of $\mathrm{SiC}$ oxidation resistance in steam and an acceleration of $\mathrm{H}_{2}$ production (to $700 \sim 800 \mathrm{~L} / \mathrm{h} / \mathrm{m}^{2} \mathrm{SiC}$ ). Above $2000{ }^{\circ} \mathrm{C}$ (point d), a significant increase of $\mathrm{H}_{2}$ production (up to $1000 \mathrm{~L} / \mathrm{h} / \mathrm{m}^{2} \mathrm{SiC}$ ) was observed. However, the causes of this final increase are not fully understood.
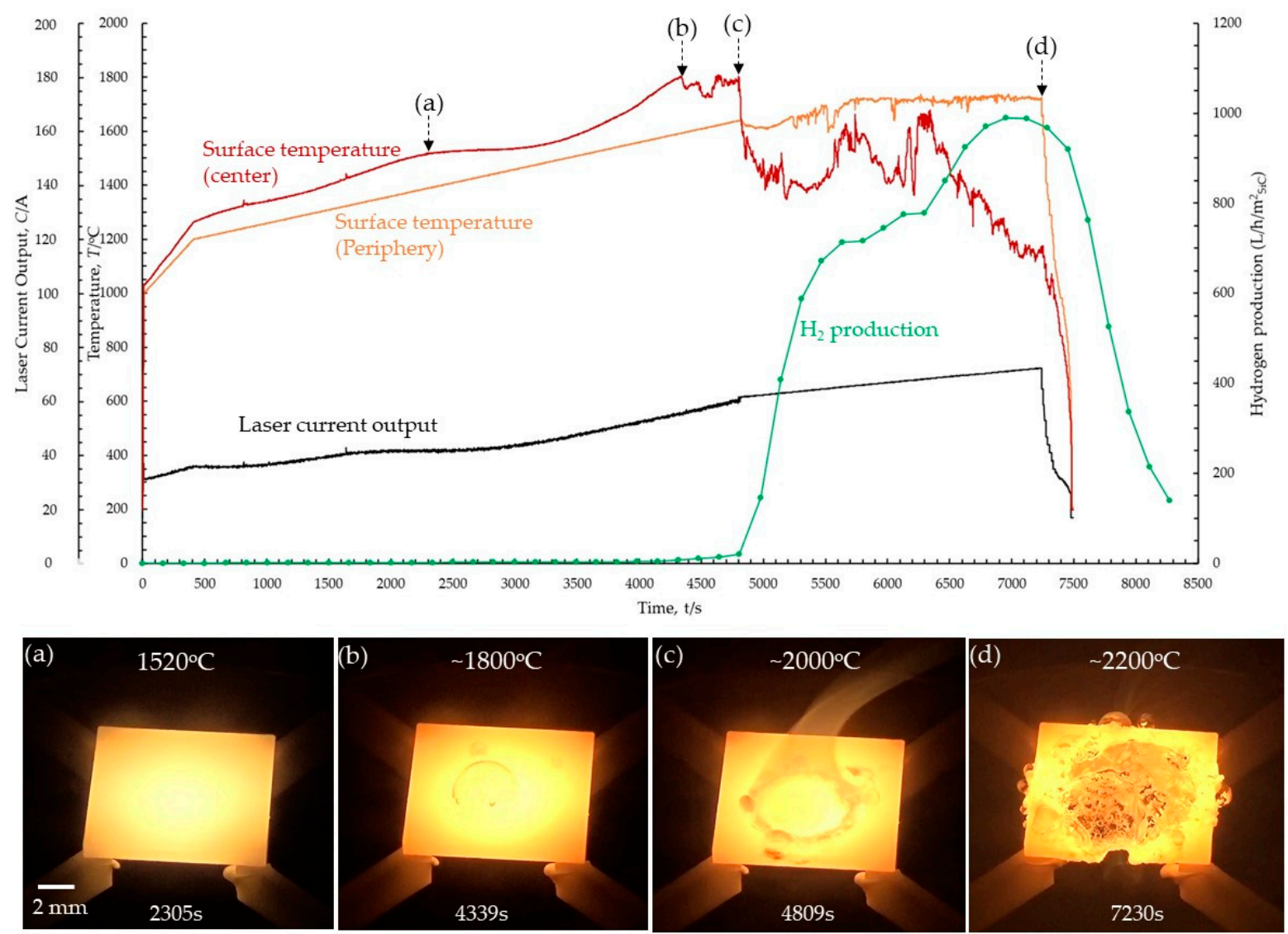

Figure 10. Experimental data (laser current, sample temperatures detected by pyrometers, hydrogen productions, and sample observation) of steam oxidation test for CVD-SiC/SiC composites using the laser heating facility (LAHF) [56].

\subsection{QUENCH-SR Facility}

The QUENCH-SR (single rod) facility at KIT Karlsruhe with inductive heating and the possibility of quenching of the samples by water is applied for steam oxidation tests to very high temperatures. The samples are enclosed in a quartz glass tube allowing observation of the tested sample by video recording. A water-cooled copper coil surrounding the quartz 
glass tube generates a magnetic field inducing eddy currents in an electrically conductive sample. The power is provided by a high frequency (HF) generator with a power of $20 \mathrm{~kW}$ working at a frequency up to $700 \mathrm{kHz}$. The temperature is measured and controlled via a two-color pyrometer (type IGAR 12-LO MB22) with a measuring range of 500 to $2200{ }^{\circ} \mathrm{C}$ working at the wavelengths $1.28 \mu \mathrm{m}$ and $1.65 \mu \mathrm{m}$. Additionally, thermocouples can be attached on the surface of the samples. Gas supply is controlled by a Bronkhorst ${ }^{\circledR}$ gas flow controller, water flow controller, and a CEM (controlled evaporator and mixer). Usually, there is $40 \mathrm{~L} / \mathrm{h}(\max .100 \mathrm{~L} / \mathrm{h})$ argon flow through the facility throughout all tests, and $60 \mathrm{~g} / \mathrm{h}(\max .75 \mathrm{~g} / \mathrm{h})$ steam is injected during the oxidation phases resulting in a steam concentration of $65 \mathrm{vol} \%$.

For metallic samples, the heating power is directly produced in the sample. $\mathrm{SiC}$ samples, however, are filled with graphite (used as a susceptor for the HF inductive heating purpose [46]) and tightly sealed with end caps at both sides to avoid interaction of the graphite with the oxidizing steam atmosphere. This heating method results in uniform and prototypical heat generation for cladding tube samples as in fuel rods, where the heat is also produced by the $\mathrm{UO}_{2}$ fuel within the cladding. Figure 11 provides some illustrations of the facility and typical samples.

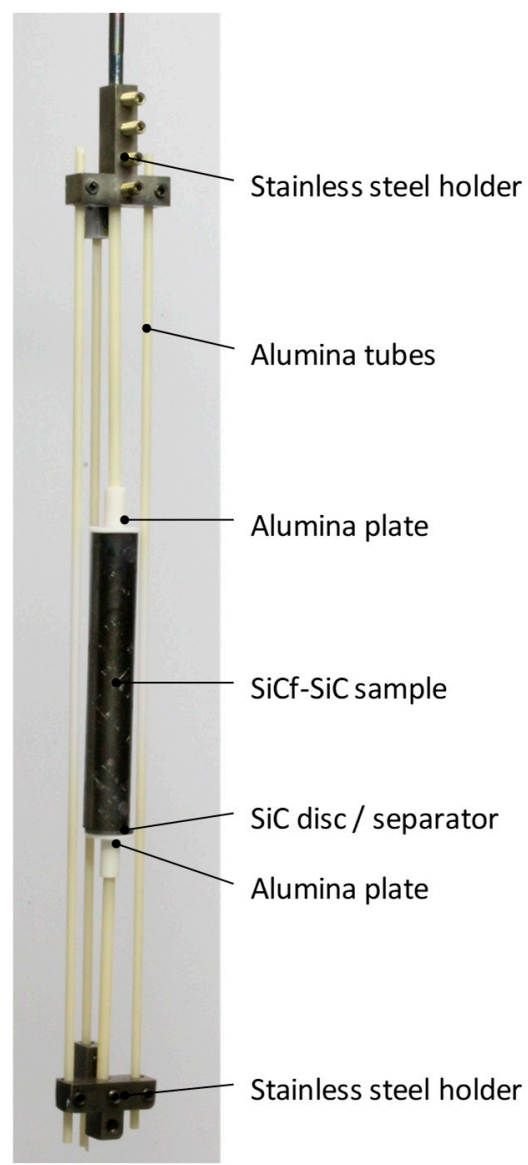

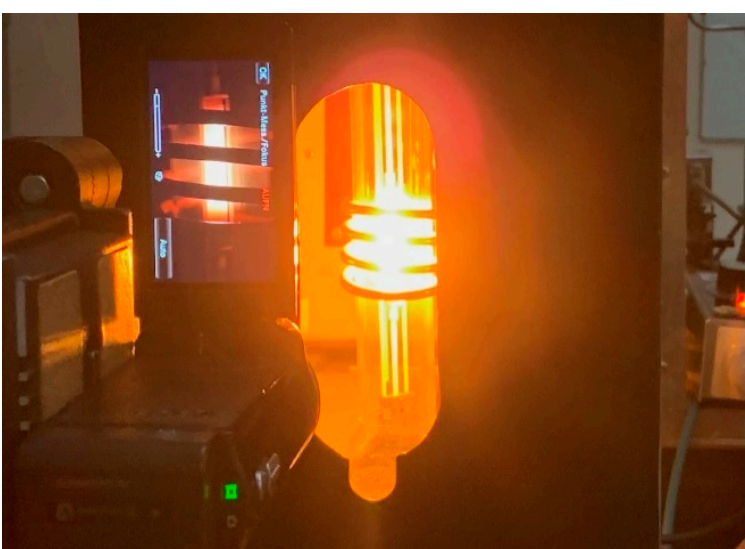

QUENCH-SR with sample and video recording at approx. $1800^{\circ} \mathrm{C}$
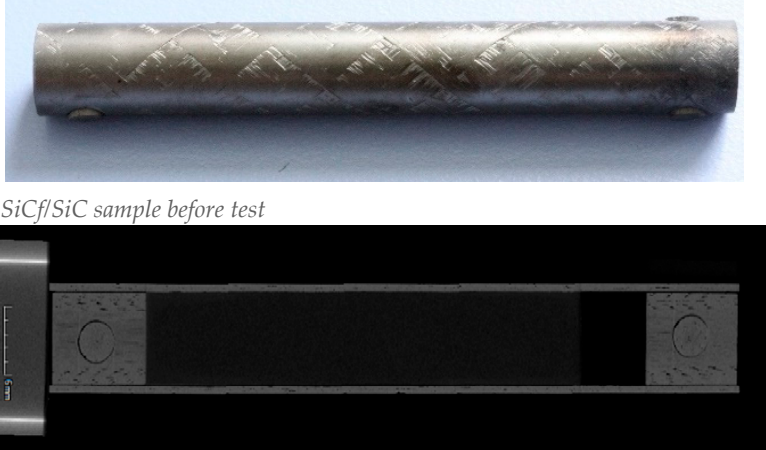

SiCf-SiC sample before test (tomography)

Figure 11. QUENCH-SR facility and SiCf-SiC sample with graphite susceptor.

A number of experiments with $\mathrm{SiC}_{\mathrm{f}}$-SiC ceramic-matrix composite (CMC) cladding tubes from various manufactures have been conducted already with this facility. Figure 12 provides, as one example, results of a transient test with such a cladding tube segment from $1400{ }^{\circ} \mathrm{C}$ to $2000{ }^{\circ} \mathrm{C}$ [46], which correspond very well to the results obtained with smaller CVD-SiC samples in the LAHF facility. According to the gas release data (Figure 12b), which are a measure for the oxidation kinetics, a protective silica scale should have formed 
immediately after start of steam injection. The minimum of gas release rates at approximately $1600{ }^{\circ} \mathrm{C}$, which is an indication of the beginning of volatilization from the oxide scale. From approximately $1750-1800{ }^{\circ} \mathrm{C}$, in addition to the baseline, huge peaks of $\mathrm{H}_{2}, \mathrm{CO}$, and $\mathrm{CO}_{2}$ releases are observed as large bubbles burst, as described above. Smoke ( $\mathrm{SiO}-\mathrm{OH}$ vapor) is also formed at temperatures above $1900{ }^{\circ} \mathrm{C}$. The test was terminated at approximately $2000^{\circ} \mathrm{C}$ by flooding a quartz glass cylinder with water from below. The sample was superficially degraded, but it survived these extreme conditions without breaking.

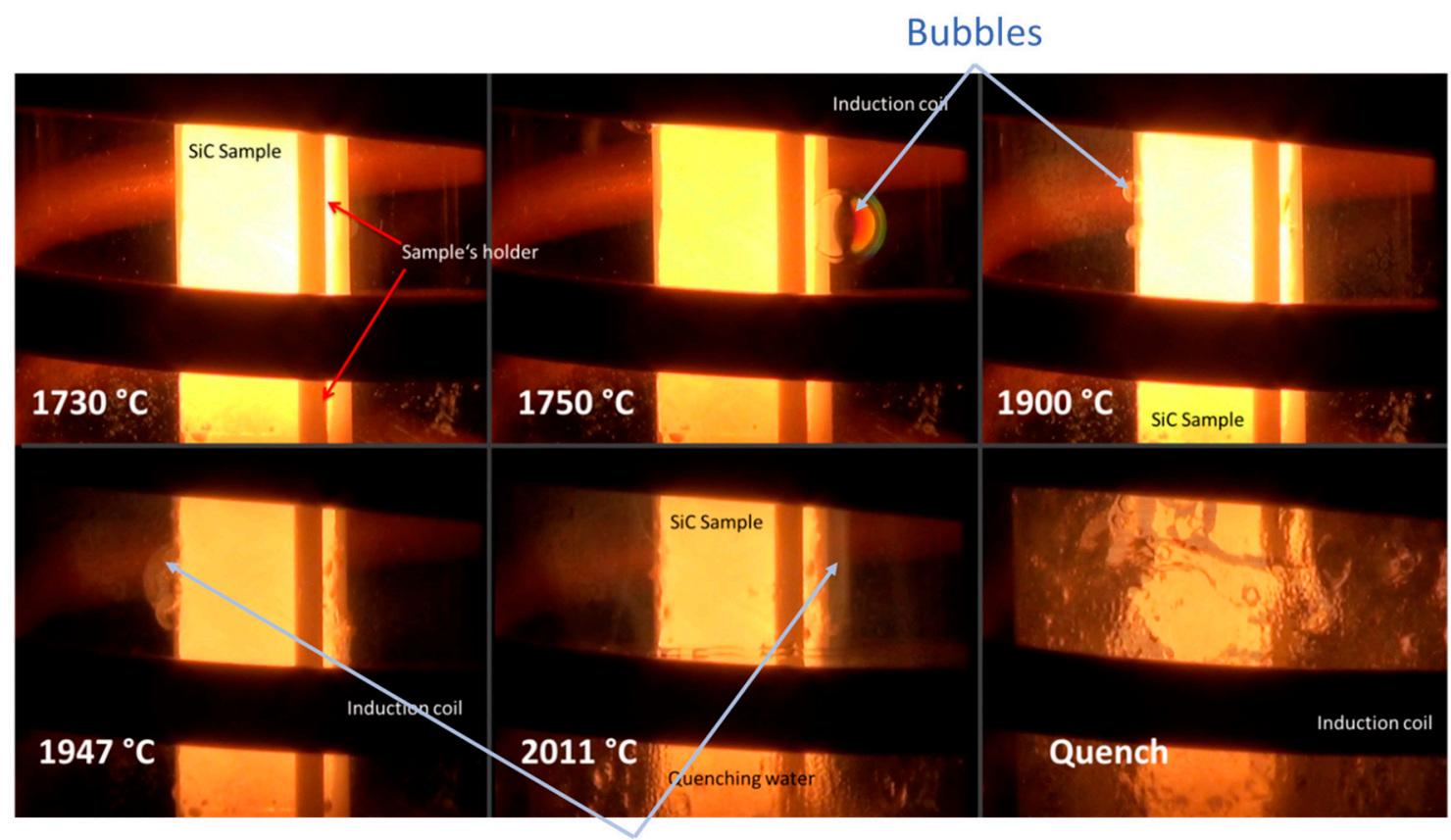

$\mathrm{Si}-\mathrm{O}-\mathrm{OH}$ smoke

(a) Video snapshots taken at temperatures between $1700^{\circ} \mathrm{C}$ and $2000^{\circ} \mathrm{C}$

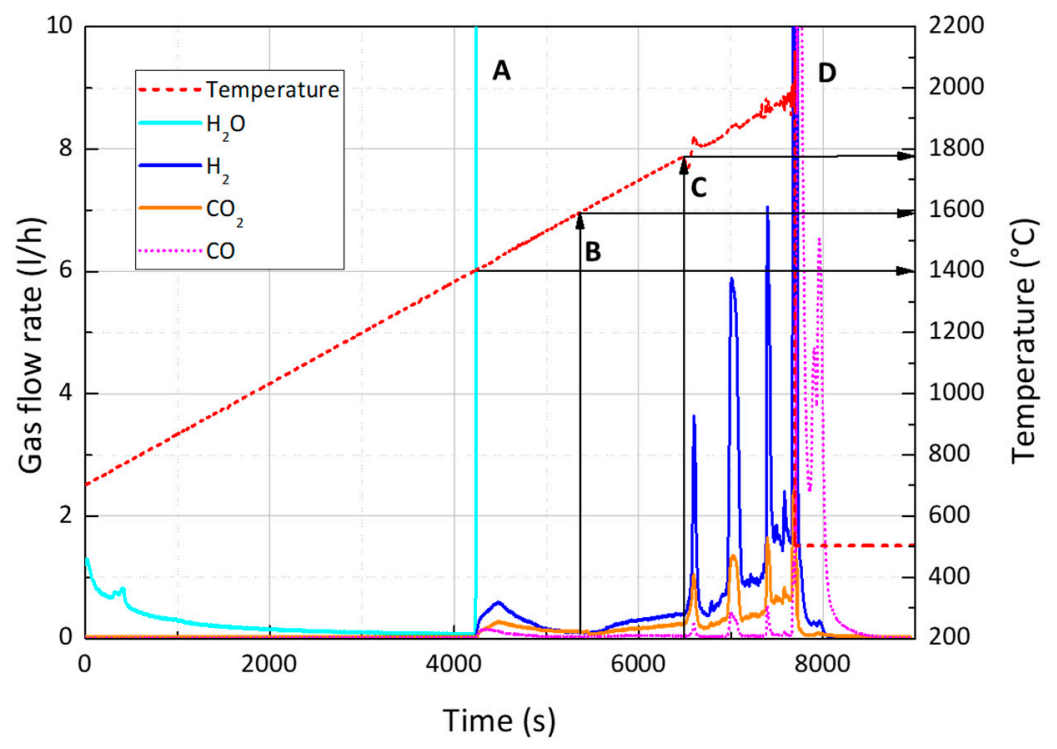

(b) Temperature and gas release during this ramp test

Figure 12. Results of a steam oxidation ramp test with a $\mathrm{SiC}$ cladding tube segment at temperatures between $1400{ }^{\circ} \mathrm{C}$ and $2000{ }^{\circ} \mathrm{C}$ [46]. 


\section{Recent Findings in Advanced Test Facilities}

\subsection{Oxidation Kinetics of SiC in Steam at Temperatures Up to $1800{ }^{\circ} \mathrm{C}$}

With the development of LAHF, oxidation tests of monolithic $\mathrm{SiC}$ under a pressure of 1 bar, in a stream of $97 \% \mathrm{H}_{2} \mathrm{O} / \mathrm{Ar}$ gas mixture, at a temperature range of $1400-1800{ }^{\circ} \mathrm{C}$, were made possible and reported in the previous study [47]. Up to $1800{ }^{\circ} \mathrm{C}$, the $\mathrm{SiC}$ samples underwent a mass loss process, which obeyed paralinear kinetics. Based on the mass change data, the parabolic oxidation rate, $k_{\mathrm{p}}$ (see Figure 6), and the linear volatilization rate, $k_{1}$ (see Figure 5), were calculated. Comparison of parabolic oxidation rate obtained from this investigation is compared with the other work in Figure 6. The parabolic oxidation rate, $k_{\mathrm{p}}$, obtained by using LAHF on monolithic $\mathrm{SiC}$ under $97 \% \mathrm{H}_{2} \mathrm{O} / \mathrm{Ar}$ gas (1 bar), up to $1800{ }^{\circ} \mathrm{C}$ seemed to have the same activation energy (approximately $96 \mathrm{~kJ} / \mathrm{mol}$ ) with the one reported by Opila [45], which was conducted by using fused quartz tube furnace. In another study, in which steam oxidation tests of $\mathrm{SiC}$ was conducted in alumina tubes, Terrani [13] reported an activation energy of parabolic oxidation rate of $238 \mathrm{~kJ} / \mathrm{mol}$. As reported elsewhere [42,51], the use of alumina tube with water vapor substantially increased the parabolic oxidation rate $k_{\mathrm{p}}$ of $\mathrm{SiC}$ due to the residual volatile sodium impurities. Because of the characteristics of LAHF facility (only the $\mathrm{SiC}$ sample was heated up to high temperature, the influence of the impurities from the environment was reduced. Therefore, the data of oxidation kinetics at high temperatures obtained from the LAHF facility best fit with the data reported by Opila [42,45], which were obtained in a high purity quartz tube. In summary, the study of $\mathrm{SiC}$ steam oxidation by using the LAHF is the first study that ranges up to $1800^{\circ} \mathrm{C}$. However, $\mathrm{SiC}$ oxidation kinetics above $1800^{\circ} \mathrm{C}$ need further investigation as the $\mathrm{SiC}$ properties particularly viscosity and volatility are clearly changing the $\mathrm{SiO}_{2}$ scale in this range.

\subsection{Oxide Scale and Bubble Formation}

The oxidation resistance of $\mathrm{SiC}$ at high temperatures relies on the formation of a protective $\mathrm{SiO}_{2}$ scale. The influence of even small amounts (ppm levels) of impurities, such as alkali metals and aluminum, on oxidation kinetics of $\mathrm{SiC}$ has been reported in various studies $[42,57,58]$. These impurities may come from various sources, such as reaction tubes, residual additives/impurities from the tested sample, or the oxidizing atmosphere. The impurities will modify the $\mathrm{SiO}_{2}$ melting point, but also its microstructure and properties, and enhance the diffusion of oxidizing species through the scale. However, from the elastic behavior observed in the LAHF and QUENCH-ATF experiments, the $\mathrm{SiO}_{2}$ layer formed at high temperatures on the $\mathrm{SiC}$ is likely to be in a glassy (rather than a crystalline) form. The glassy form has $\mathrm{SiO}_{2}$ tetrahedra chains with -O- bridging links, has a so-called glass transition point followed by a softening range. The chain length determines the transition point and softening range. In glass-making, small additions of alkali metal oxides are known reduce the chain lengths in silica melts and lower their viscosity [59]. Thus, amorphous/glassy phases formed between the impurities and silica may also be more permeable and volatile than the pure silica.

Bubble formation of $\mathrm{SiC}$ in steam has been reported in a number of studies $[13,45-47]$. Avincola [46] discussed three criteria, which have to be fulfilled for the formation of bubbles: (1) the formation of a dense, complete silica scale, (2) the presence of a higher gas pressure at the $\mathrm{SiC} / \mathrm{SiO}_{2}$ interface, and (3) sufficiently low viscosity of the silica scale. The impurities have been demonstrated to be able to significantly affect the viscosity of silica [60-62]. It means the less impurities the $\mathrm{SiO}_{2}$ layer has, the higher temperature the bubble phenomenon occurs at and may explain the formation of bubbles over a wide range of temperatures with various bubble sizes.

Pressure may also influence the formation of $\mathrm{SiO}_{2}$ bubbles. Currently, most of the oxidation studies for $\mathrm{SiC}$ at high temperature in steam were conducted at atmospheric pressure. High pressure environments in LWRs (60 bar before any depressurization phenomena) might suppress the formation of $\mathrm{SiO}_{2}$ bubble at high temperatures. Nevertheless, 
it remains necessary to conduct oxidation tests of $\mathrm{SiC}$ in high-pressure steam. Investigating the effect of controlled impurities on $\mathrm{SiO}_{2}$ layer properties is a further aspect for testing.

\subsection{Tests with Prototypical SiC-Based Cladding Tubes}

More prototypical tests in the QUENCH-SR rig have confirmed the results obtained in the LAHF facility. The transient tests showed the same temperature ranges for stable and protective $\mathrm{SiO}_{2}$ oxide scale formation, as well as for the development of bubbles and increasing volatilization of the silica scale in this temperature range. Isothermal tests confirmed the stability of such $\mathrm{SiC}$-based cladding for a few hours up to $170{ }^{\circ} \mathrm{C}$. Longer term testing is also necessary to determine these limits. A rapidly enhanced oxidation kinetics is always observed when the superficial monolithic $\mathrm{SiC}$ environmental barrier layer (or seal-coat) failed, which gave access of the oxidizing atmosphere to the fiber-matrix composite [63]. The main reason for this dramatically increased oxidation kinetics, then, is the much higher accessible surface of the CMC system and the graphite-based fibermatrix interface, which easily oxidizes. The temperature and time of CMC failure is mainly determined by the thickness and quality, respectively, of the external monolithic $\mathrm{SiC}$ layer. Most samples remained intact even during water quenching from temperatures of $1700{ }^{\circ} \mathrm{C}$ to $2000{ }^{\circ} \mathrm{C}$.

\section{Summary and Perspective}

The steam oxidation of $\mathrm{SiC}$ at high temperatures and advanced facilities for accident tolerant fuel (ATF) cladding testing have been reviewed. In spite of many potential benefits, such as superior high-temperature properties and excellent irradiation resistance, there remain key issues, such as steam oxidation at extreme temperatures $\left(1800-2000{ }^{\circ} \mathrm{C}\right)$, that needed to be addressed for LWR safety issues. Due to the lack of appropriate test facilities, study of oxidation behavior of $\mathrm{SiC}$ in steam at temperatures above $1600{ }^{\circ} \mathrm{C}$ was very challenging. Recent developments using remote heating and sensing (eddy current heating, laser heating, and pyrometry) have enabled oxidation studies to be carried out for $\mathrm{SiC}$ in steam up to $2000{ }^{\circ} \mathrm{C}$. A summary of these developments and experiments are presented as follows:

- Development of non-contact heating and measurement techniques provide unique tools for studying of materials behavior in severe environments, which were not possible before. Further common features include localized heating of small sample masses allowing for high heating rates and avoiding contamination other materials of the facility, such as the support plate. All this occurs under fixed atmospheric conditions.

- Investigations conducted using the LAHF successfully yielded the $\mathrm{SiC}$ steam oxidation kinetics up to $1800^{\circ} \mathrm{C}$. The LAHF data at $1400-1800^{\circ} \mathrm{C}$ are in good agreement with the data obtained at $1200-1400{ }^{\circ} \mathrm{C}$ by Opila. It indicated a similar $\mathrm{SiC}$ steam oxidation mechanism existed up to $1800^{\circ} \mathrm{C}$ as was valid at $1400{ }^{\circ} \mathrm{C}$. In other words, the excellent oxidation resistance of $\mathrm{SiC}$ in steam (producing relatively less heat and hydrogen gas) was maintained at temperatures up to $1800^{\circ} \mathrm{C}$. Investigation of $\mathrm{SiC}$ steam oxidation in conducted with the QUENCH-SR facility also confirmed the excellent performance of $\mathrm{SiC}$, as prototypical $\mathrm{SiC}$ cladding samples remained intact even after quenching with water from $2000{ }^{\circ} \mathrm{C}$.

- Future works: In spite of these recent efforts, further investigations of SiC steam oxidation in for a wider range of conditions should be carried out. For example, recent studies on steam oxidation of $\mathrm{SiC}$ were conducted in very clean environments. It is, therefore, necessary to conduct high temperature $\mathrm{SiC}$ steam oxidation tests under various impure environments, such as $\mathrm{Cl}^{-}, \mathrm{SO}_{4}{ }^{2-}, \mathrm{Ca}^{2+}$, or $\mathrm{Na}^{+}$-containing steam (from sea water). Tests under high pressure conditions of $\mathrm{SiC}$ steam oxidation of at high temperatures or pressure cycles should also be conducted to reflect the pressurization /depressurization cycles during reactor accidents. Furthermore, this new data of high-temperature $\mathrm{SiC}$ steam oxidation kinetics needs to be tested to the highest available temperatures and to the longest times possible particularly for 
operating fuel temperatures cycling in larger-scale experiments as planned in the QUENCH bundle facility at KIT. This is expected in the framework of the forthcoming OECD-NEA Joint Undertaking QUENCH-ATF [64].

Author Contributions: Writing—original draft preparation, H.V.P.; writing-review and editing, M.K. and M.S. All authors have read and agreed to the published version of the manuscript.

Funding: A part of this article refers to the result of "Development of Technical Basis for Introducing Advanced Fuels Contributing to Safety Improvement of Current Light Water Reactors" carried out under the Project on Development of Technical Basis for Improving Nuclear Safety by Ministry of Economy, Trade and Industry (METI) of Japan.

Institutional Review Board Statement: Not applicable.

Informed Consent Statement: Not applicable.

Data Availability Statement: Not applicable.

Acknowledgments: The authors wish to express their appreciation to Hitachi-GE Nuclear Energy, Ltd.; Mitsubishi Nuclear Fuel Co. Ltd.; and Toshiba Energy Systems and Solutions Corporation for providing test pieces during the investigations via LAHF facility. The authors also would like to gratefully acknowledge David Bottomley for his kind support and advice.

Conflicts of Interest: The authors declare no conflict of interest. The funders had no role in the design of the study; in the collection, analyses, or interpretation of data; in the writing of the manuscript, or in the decision to publish the results.

\section{References}

1. Kurata, M.; Barrachin, M.; Haste, T.; Steinbrueck, M. Phenomenology of BWR fuel assembly degradation. J. Nucl. Mater. 2018, 500, 119-140. [CrossRef]

2. Hofmann, P.; Markiewicz, M.; Spino, J. Reaction behavior of $\mathrm{B}_{4} \mathrm{C}$ absorber materials with stainless steel and zircaloy in severe light water reactor accidents. Nucl. Technol. 1990, 90, 226-244. [CrossRef]

3. Nagase, F.; Uetsuka, H.; Otomo, T. Chemical interactions between $\mathrm{B}_{4} \mathrm{C}$ and stainless steel at high temperatures. J. Nucl. Mater. 1997, 245, 52-59. [CrossRef]

4. Shibata, H.; Sakamoto, K.; Ouchi, A.; Kurata, M. Chemical interaction between granular B ${ }_{4}$ C and 304L-type stainless steel materials used in BWRs Japan. J. Nucl. Sci. Technol. 2015, 52, 1313-1317. [CrossRef]

5. Ueda, S.; Madokoro, H.; Jo, B.; Kondo, M.; Erkan, N.; Okamoto, K. Dynamic visualization of eutectic reaction between boron carbide and stainless steel. J. Nucl. Sci. Technol. 2017, 54, 81-88. [CrossRef]

6. Steinbrück, M. Degradation and oxidation of B4C control rod segments at high temperatures. J. Nucl. Mater. 2010, 400, 138-150. [CrossRef]

7. Steinbrueck, M. Influence of Boron Carbide on Core Degradation During Severe Accident in LWRs. Ann. Nucl. Energy 2014, 64, 43-49. [CrossRef]

8. Kim, K.; Olander, D. Dissolution of Uranium dioxide by molten zircaloy, II. Convection-controlled reaction. J. Nucl. Mater. 1988, 154, 102-115. [CrossRef]

9. Hayward, P.; George, I. Dissolution of UO2 in motlen zircaloy-4 Part 1: Solubility from 2000 to $2200{ }^{\circ} \mathrm{C}$. J. Nucl. Mater. 1994, 208, 35-42. [CrossRef]

10. Hofmann, P. Current knowledge on core degradation phenomena, a review. J. Nucl. Mater. 1999, 270, 194-221. [CrossRef]

11. NEA. State-of-the-Art Report on Light Water Reactor Accident-Tolerant Fuels; Nuclear Science; OECD Publishing: Paris, France, 2018.

12. Snead, L.; Nozawa, T.; Ferraris, M.; Katoh, Y.; Shinavski, R.; Sawan, M. Silicon carbide composites as fusion power reactor structural materials. J. Nucl. Mater. 2011, 417, 330-339. [CrossRef]

13. Terrani, K.A.; Bruce, P.; Parish, C.; Silva, C.; Snead, L.; Katoh, Y. Silicon carbide oxidation in steam up to 2 MPa. J. Am. Ceram. Soc. 2014, 97, 2331-2352. [CrossRef]

14. Pint, B.; Terrani, K.; Brady, M.; Cheng, T.; Keiser, J. High temperature oxidation of fuel cladding candidate materials in steamhydrogen environements. J. Nucl. Mater. 2013, 440, 420-427. [CrossRef]

15. Terrani, K.; Zinkle, S.; Snead, L. Advanced oxidation-resistant iron-based alloys for LWR fuel cladding. J. Nucl. Mater. 2014, 448, 420-435. [CrossRef]

16. Dryepondt, S.; Unocic, K.; Hoelzer, D.; Massey, C.; Pint, B. Development of low-Cr FeCrAl alloys for accident-tolerant fuel cladding. J. Nucl. Mater. 2018, 501, 59-71. [CrossRef]

17. Park, H.; Kim, G.; Park, Y.; Jung, I.; Park, J.; Koo, H. High temperature steam-oxidation behavior of arc ion plated Cr coatings for accident tolerant fuel claddings. Surf. Coat. Technol. 2015, 280, 256-259. [CrossRef]

18. Tang, C.; Stueber, M.; Seifert, H.; Steinbrueck, M. Protective coatings on zirconium-based alloys as accident-tolerant fuel (ATF) claddings. Corros. Rev. 2017, 35, 141-165. [CrossRef] 
19. Pint, B.; Terrani, K.; Yamamoto, Y.; Snead, L. Material selection for accident tolerant fuel cladding. Metall. Mater. Trans. E 2015, 2, 190-196. [CrossRef]

20. Terrani, K. Accident tolerant fuel cladding development: Promise, status, and challenges. J. Nucl. Mater. 2018, 501, 13-30. [CrossRef]

21. Hironaka, K.; Nozawa, T.; Hinoki, T.; Igawa, N.; Kotoh, Y.; Snead, L.; Kohyama, A. High-temperature tensile strength of near-stoichiometric SiC/SiC composites. J. Nucl. Mater. 2002, 307-311, 1093-1097. [CrossRef]

22. Shimoda, K.; Hinoki, T.; Kishimoto, H.; Kohyama, A. Enhanced high-temperature performances of SiC/SiC composites by high densification and crystalline structure. Compos. Sci. Technol. 2011, 71, 326-332. [CrossRef]

23. Katoh, Y.; Snead, L.; Szlufarska, I.; Weber, W. Radiation effects in SiC for nuclear structural applications. Curr. Opin. Solid State Mater. Sci. 2012, 16, 143-152. [CrossRef]

24. Katoh, Y.; Ozawa, K.; Hinoki, T.; Choi, Y.; Snead, L.; Hasegawa, A. Mechanical properties of advanced SiC fiber composites irradiated at very high temperatures. J. Nucl. Mater. 2011, 417, 416-420. [CrossRef]

25. Deck, C.; Jacobsen, G.; Sheeder, J.; Gutierrez, O.; Zhang, J.; Stone, J.; Khalifa, H.; Back, C. Characterization of SiC-SiC composites for accident tolerant fuel cladding. J. Nucl. Mater. 2015, 466, 667-681. [CrossRef]

26. Snead, L.; Nozawa, T.; Katoh, Y.; Byun, T.; Kondo, S.; Petti, D. Handbook of SiC properties for fuel performance modeling. J. Nucl. Mater. 2007, 371, 329-377. [CrossRef]

27. Kim, W.; Kim, D.; Park, J. Fabrication and material issues for the application of SiC composites to LWR fuel cladding. Nucl. Eng. Technol. 2013, 45, 565-572. [CrossRef]

28. Katoh, Y.; Terrani, K.; Snead, L. Systematic technology evaluation program for SiC/SiC composite-based accident-tolerant LWR fuel cladding and core structures. In Accident Tolerant Fuel Concepts for Light Water Reactors, Proceedings of the Technical Meeting, Oak Ridge, AP, USA, 10-13 June 2014; IAEA: Vienna, Austria, 2016.

29. Hinze, J.; Graham, H. The active oxidation of Si and SiC in the viscous gas-flow regime. J. Electrochem. Soc. 1976, 123, 1066-1073. [CrossRef]

30. Cappelen, H.; Johansen, K.; Motzfeldt, K. Oxidation of silicon carbide in oxygen and in water vapour at $1500{ }^{\circ} \mathrm{C}$. Acta Chem. Scand. A 1981, 35, 247-254. [CrossRef]

31. Narushima, T.; Goto, T.; Iguchi, Y.; Hirai, T. High temperature active oxidation of chemically vapor-deposited silicon carbide in an Ar-O2 atmospheres. J. Am. Ceram. Soc. 1991, 74, 2583-2586. [CrossRef]

32. Opila, E.; Nguyen, Q. Oxidation of chemically-vapor-deposited silicon carbide in carbon dioxide. J. Am. Ceram. Soc. 1998, 81, 1949-1952. [CrossRef]

33. Steinbrueck, M.; Avincola, V.A.; Markel, I.; Stegmaier, U.; Gerhards, U.; Seifert, H. Oxidation of SiCf-SiC CMC cladding tubes for GFR application in impure helium atmosphere and materials interactions with tantalum liner at high temperatures up to $1600{ }^{\circ} \mathrm{C}$. J. Nucl. Mater. 2019, 517, 337-348. [CrossRef]

34. Balat, M.; Glamant, G.; Male, G.; Pichelin, G. Active to passive transition in the oxidation of silicon carbide at high temperature and low pressure in molecular and atomic oxygen. J. Mater. Sci. 1992, 27, 679-703. [CrossRef]

35. Mieskowshi, D.; Mitchell, T.; Heuer, A. Bubble formation in oxide scale on SiC. J. Am. Ceram. Soc. 1984, 67, C-17-C-18.

36. Narushima, T.; Goto, T.; Yokoyama, Y.; Takeuchi, M.; Iguchi, Y.; Hirai, T. Active-to-passive transition and bubble formation for high-temperature oxidation of chemically vapor-deposited silicon carbide in CO-CO2 atmosphere. J. Am. Ceram. Soc. 1994, 77, 1079-1082. [CrossRef]

37. Goto, T.; Homma, H. High-temperature active/passive oxidation and bubble formation of CVD SiC in $\mathrm{O} 2$ and CO2 atmospheres. J. Euro. Ceram. Soc. 2002, 22, 2749-2756. [CrossRef]

38. Goto, T. High Temperature Oxidation Behavior of Chemical Vapor Deposited Silicon Carbide. J. Ceram. Soc. Jap. 2002, 110, 884-889. [CrossRef]

39. Jacobson, N.; Myers, D. Active Oxidation of SiC. Oxid. Met. 2011, 75, 1-25. [CrossRef]

40. Narushima, T.; Goto, T.; Hirai, T.; Iguchi, Y. High-Temperature Oxidation of Silicon Carbide and Silicon Nitride. Mater. Trans. 1997, 38, 821-835. [CrossRef]

41. Opila, E.; Robinson, R. The oxidation rate of $\mathrm{SiC}$ in high pressure water vapor environments. In High Temperature Corrosion and Materials Chemistry; McNallan, M., Opila, E., Maruyama, T., Narita, T., Eds.; The Electrochemical Society, Inc.: Pennington, NJ, USA, 2000; pp. 398-406.

42. Opila, E.; Hann, E.J. Paralinear oxidation of CVD SiC in water vapor. J. Am. Ceram. Soc. 1997, 80, 197-205. [CrossRef]

43. Tedmon, C. The effect of oxide volatilization on the oxidation kinetics of Cr and Fe-Cr alloys. J. Electrochem. Soc. 1966, 113, 766-768. [CrossRef]

44. Jorgensen, P.; Wadsworth, M.; Cutler, I. Effects of water vapor on oxidation of silicon carbide. J. Am. Ceram. Soc. 1961, 44, 258-261. [CrossRef]

45. Opila, E. Variation of the oxidation rate of silicon carbide with water-vapor pressure. J. Am. Ceram. Soc. 1999, 82, 625-636. [CrossRef]

46. Avincola, V.; Grosse, M.; Stegmaier, U.; Steinbrueck, M.; Seifert, H. Oxidation at high temperatures in steam atmosphere and quench of silicon carbide composites for nuclear application. Nucl. Eng. Des. 2015, 195, 468-478. [CrossRef]

47. Pham, H.; Nagae, Y.; Kurata, M.; Bottomley, D.; Furumoto, K. Oxidation kinetics of silicon carbide in steam at temperature range of 1400 to $1800{ }^{\circ} \mathrm{C}$ studied by laser heating. J. Nucl. Mater. 2020, 529, 151939. [CrossRef] 
48. Narushima, T.; Goto, T.; Iguchi, Y.; Hirai, T. High-temperature oxidation of chemically vapor-deposited silicon carbide in wet oxygen at 1823 to 1923 K. J. Am. Ceram. Soc. 1990, 73, 3580-3584. [CrossRef]

49. Robinson, R.; Smialek, J. SiC Recession Caused by $\mathrm{SiO}_{2}$ Scale Volatility under Combustion Condition: I, Experimental Results and Empirical Model. J. Am. Ceram. Soc. 1999, 82, 1817-1825. [CrossRef]

50. Opila, E.; Smialek, J.; Robinson, R.; Fox, D.; Jacobson, N. SiC Recession Caused by $\mathrm{SiO}_{2}$ Scale Volatility under Combustion condition: II, Thermodynamics and Gaseous-Diffusion Model. J. Am. Ceram. Soc. 1999, 82, 1826-1834. [CrossRef]

51. Opila, E. Oxidation kinetics of chemically vapor-deposited silicon carbide in wet oxygen. J. Am. Ceram. Soc. 1994, 77, 730-736. [CrossRef]

52. Deal, B.; Grove, A. General relationship for the thermal oxidation of silicon. J. Appl. Phys. 1965, 36, 3770-3778. [CrossRef]

53. Doremus, R. The diffusion of water in fused silica. In Reactivity of Solids; Mitchell, J., DeVries, C., Roberts, R., Cannon, P., Eds.; Wiley-Interscience: New Work, NY, USA, 1969; pp. 667-673.

54. Robb, K.; Francis, M.; Ott, L. Insight from Fukushima Daiichi Unit 3 investigations using MELCOR. Nucl. Technol. 2014, 186, 145-160. [CrossRef]

55. Stuckert, J.; Große, M.; Rössger, C.; Klimenkov, M.; Steinbrück, M.; Walter, M. QUENCH-LOCA program at KIT on secondary hydriding and results of the commissioning bundle test QUENCH-LO. Nucl. Eng. Des. 2013, 255, 185-201. [CrossRef]

56. Pham, H.V.; Ishibashi, R.; Nagae, Y.; Kurata, M. Performance of Silicon carbide in steam at high temperatures as accident tolerant fuel cladding. Unpublished work.

57. Pareek, V.; Shores, D. Oxidation of silicon carbide in environments containing Potassium salt vapor. J. Am. Ceram. Soc. 1991, 74, 556-563. [CrossRef]

58. Zheng, Z.; Tressler, R.; Spear, K. The effect of sodium contamination on the oxidation of single crystal silicon carbide. Corros. Sci. 1992, 33, 545-556. [CrossRef]

59. Isard, J.O. The mixed alkali effect in glass. J. Non-Cryst. Solids 1969, 1, 235-261. [CrossRef]

60. Doremus, R. Viscosity of silica. J. Appl. Phys. 2002, 92, 7619-7629. [CrossRef]

61. Bihuniak, P.; Calabrese, A.; Erwin, E. Effect of trace impurity levels on the viscosity of vitreous silica. J. Am. Ceram. Soc. 1983, 66, C-134-C-135. [CrossRef]

62. Yamahara, K.; Shima, K.; Utsunomiya, A.; Tsurita, Y. Viscosity of silica glass prepared from sol-gel powder. J. Non-Cryst. Solids 2004, 349, 341-346. [CrossRef]

63. Steinbrueck, M.; Grosse, M.; Stegmaier, U.; Braun, J.; Lorrette, C. High-Temperature Oxidation of Silicon Carbide Composites for Nuclear Applications; TopFuel: Santander, Spain, 2021.

64. NEA. Available online: https://www.oecd-nea.org/jcms/pl_36597/quench-atf-project (accessed on 31 May 2021). 